\title{
AC 2008-1100: DESIGNING A CIVIL ENGINEERING PROGRAM FOR THE NATIONAL MILITARY ACADEMY OF AFGHANISTAN
}

\section{Stephen Ressler, United States Military Academy}

Colonel Stephen Ressler, P.E. is Professor and Head of the Department of Civil and Mechanical Engineering at the U.S. Military Academy (USMA) at West Point. He earned a B.S. degree from USMA in 1979, a Master of Science in Civil Engineering degree from Lehigh University in 1989, and a Ph.D. from Lehigh in 1991. An active duty Army officer, he has served in a variety of military engineering assignments around the world. He has been a member of the USMA faculty for 16 years, teaching courses in engineering mechanics, structural engineering, construction, and professional practice.

\section{Christopher Conley, United States Military Academy}

Chris Conley is an Associate Professor in the Department of Civil and Mechanical Engineering at the U.S. Military Academy. He earned a B.S. degree in Civil Engineering from the University of Massachusetts (1978), and M.S. and Ph.D. degrees in Civil Engineering from Cornell University $(1980,1983)$. He has served as a Member of Technical Staff at Sandia National Laboratories, a Senior Research Associate at Cornell University, and an Assistant Professor at the University of Massachusetts Lowell. In his 13 years on the USMA faculty he has taught a variety of courses in the civil and mechanical engineering programs, and has collaborated on research with Army laboratory personnel.

\section{Richard Gash, United States Military Academy}

Major Richard Gash, P.E. is an instructor in the Department of Civil and Mechanical Engineering at the U.S. Military Academy (USMA), West Point. He graduated from the USMA in 1996, earning a Bachelor of Science Degree in Civil Engineering. He has since earned Master of Science Degrees in Geophysics from the University of Missouri, Rolla and Earthquake Engineering from the University of California, Los Angeles. As an active duty Army officer he has served in a variety of military assignments around the world including Iraq and Afghanistan. During the summer of 2007 he served as a member of the Combined Security Transition Command's Implementation and Support team at the National Military Academy of Afghanistan. 


\section{Designing a Civil Engineering Program for the National Military Academy of Afghanistan}

This paper describes the ongoing development of a civil engineering program for the newly created National Military Academy of Afghanistan (NMAA) in Kabul. Program development tasks included the design of curriculum and courses, development of laboratories, and hiring of faculty. The authors are U.S. Military Academy faculty members who deployed to Afghanistan in the spring and summer of 2007 to establish the new program at NMAA. In this paper, we describe our processes, products, and lessons learned. Although the situation in Afghanistan is unique in many ways, the lessons we learned there are nonetheless applicable to engineering capacity-building projects elsewhere in the developing world as well.

\section{Background}

Early in 2003, Afghanistan's Ministry of Defense and the U.S. Army's Office of Military Cooperation - Afghanistan (OMC-A) agreed to jointly establish a military academy that would provide the newly created Afghan National Army with a capable, well-educated officer corps. ${ }^{1}$ After considering a variety of different institutional formats, the Ministry of Defense ultimately decided that the new academy would be a four-year degree-producing institution modeled on the U.S. Military Academy (USMA) at West Point. ${ }^{2}$ Based on this decision, OMC-A enlisted the assistance of USMA in creating the new academy.

Shortly thereafter, OMC-A established a small U.S. liaison team, the Military Academy Implementation Team (MAIT), based at Camp Eggers in Kabul. Starting in October 2003, a succession of volunteer USMA faculty and staff members deployed to Afghanistan to augment the MAIT with appropriate expertise in institutional governance, strategic planning, admissions, faculty development, military training, physical development, and various academic disciplines. ${ }^{3}$ These advisors were instrumental in helping the Afghans formulate a blueprint for their new academy - a mission statement, an honor code, an organizational design, and a concept plan for its academic, physical, and military development programs. The new institution was named the National Military Academy of Afghanistan (NMAA) to emphasize its intended purpose as an instrument for enhancing national unity.

Afghanistan is an ethnically diverse (and, to a large extent, ethnically divided) country, with significant Pashtun, Tajik, Hazara, Uzbek, Aimak, Turkmen, and Baloch populations. ${ }^{4}$ These ethnic groups have frequently been in conflict with each other. ${ }^{5}$ Most of Afghanistan's current political leaders recognize that, if their current democratic government is to succeed, these century-old ethnic animosities must be overcome. The new Afghan National Army is seen as an important tool for forging a true national identity and for subordinating ethnic and tribal loyalties to the democratically elected national government. As such, the Afghan National Army has been recruited from all of Afghanistan's ethnic groups, and its composition is roughly representative of the population as a whole. The NMAA has been similarly constituted, with cadets admitted and faculty hired in proportion to their respective ethnic groups' representation in the Afghan population. As a recent Wall Street Journal article noted, 
Everything at the NMAA is geared to producing a national army free of regional and ethnic biases. Even the living quarters take ethnic and regional balance into account. In one random dormitory room I visited, the 12 cadets came from all over the country. In fact, these young men have been so well drilled that random questions about unrelated issues are apt to include a reference to the fact that "we are one Army for all of Afghanistan."6

The four-year NMAA curriculum, as jointly developed by the Afghan academy leadership and their U.S. mentors, is illustrated in Figure 1 below. The eight academic semesters are indicated in the first column, and the courses offered in each semester are listed across each corresponding row. The dark horizontal bands preceding each pair of semesters represent military training periods. These periods would correspond to summers at a U.S. institution; however, at the NMAA they actually occur in the February-March timeframe, as Afghan educational institutions use the Islamic calendar as the basis for their school year.

The named courses shown in Figure 1 constitute a common core curriculum taken by all cadets. The core curriculum, consisting of 18 courses in the humanities and social sciences, 10 in mathematics and the basic sciences, and a two-course engineering sequence (highlighted in yellow), is aimed at producing broadly educated professional officers for the Afghan National Army. The six foreign language courses are all in a single language_English, French, German, or Turkish-with over half of the cadets in a typical class taking English. The remaining 15 courses constitute a major in one of four academic disciplines-civil engineering, information technology, law and political science, or English. Each major provides for the development of intellectual depth in a subject area deemed to be of importance to the future of Afghanistan.

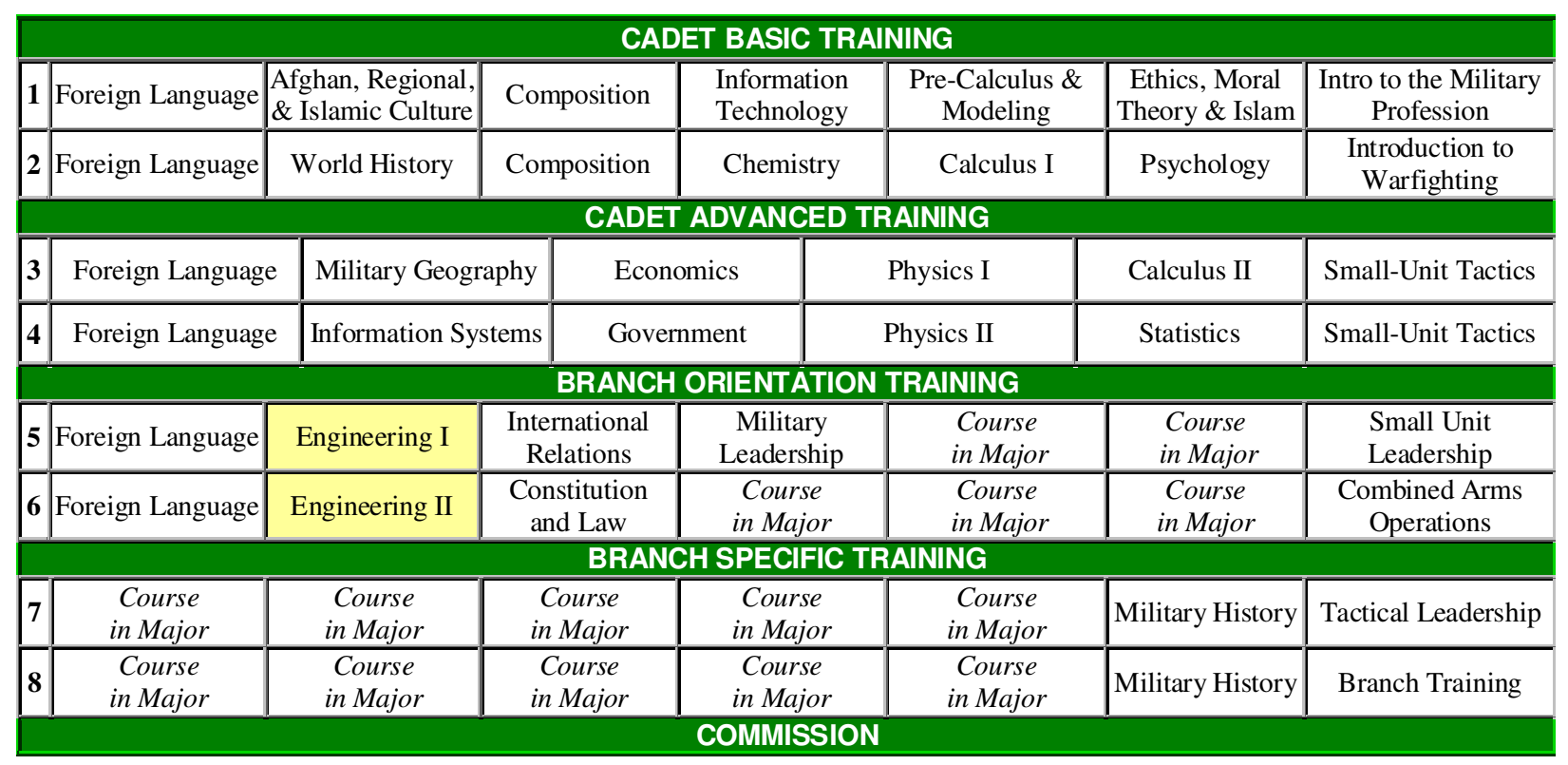

Figure 1. NMAA Curriculum

With its organization and curriculum established, the NMAA formally opened its doors on March 22, 2005. ${ }^{1} 120$ of the 353 applicants for the first class were offered admission. A sufficient number of instructors - all of whom were Afghan Army officers-had been hired to 
teach the first-year (freshman) curriculum, and future hires were planned in accordance with the four-year curriculum design. One year later, 270 of 1007 applicants were admitted into

NMAA's second class, and the original class of cadets began taking courses in the second-year (sophomore) curriculum. The academy's long-term goal is to admit enough cadets into each class to ensure that there are 300 graduates each year.

In August 2006, with the NMAA's fourth academic semester underway, the chief of the MAIT requested that USMA send a new contingent of faculty mentors who would be tasked with developing the two-course core engineering sequence and the civil engineering major. The authors volunteered for this mission. Conley and Ressler deployed from January to April 2007 to develop the civil engineering curriculum as a whole, and to design and implement the courses that would be offered in Semester 5. Gash deployed from June to August 2007, along with two faculty members from the U.S. Air Force Academy, to design and implement the Semester 6 courses. Our work consisted of four major activities-faculty hiring, curriculum design, course development, and laboratory development.

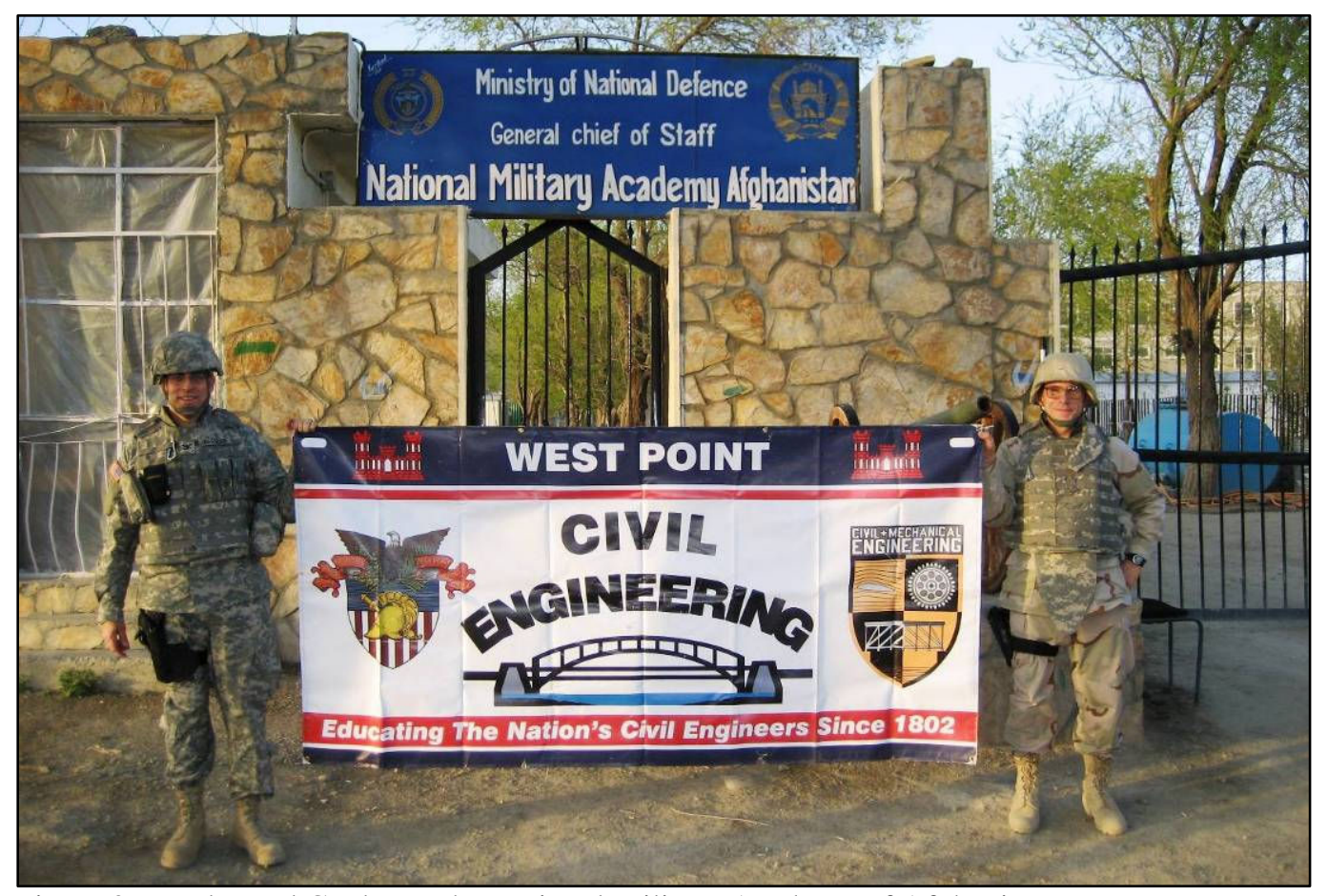

Figure 2. Ressler and Conley at the National Military Academy of Afghanistan

\section{Faculty Hiring}

For a full year prior to our deployment, the MAIT had been attempting to hire engineering faculty for the NMAA, with no success. In establishing the academy, the Afghan Ministry of Defense had instituted a policy requiring that all faculty members be Afghan military officers. By January 2007, this policy had proved to be unworkable. There were evidently no officers in the Afghan National Army with even a minimally adequate background to teach college-level engineering. At the urging of the MAIT chief, the Ministry of Defense eventually agreed to allow civilian professors from Kabul University to be hired as adjunct instructors at the NMAA. 
By the time we arrived in Kabul, the MAIT had already performed initial coordination for our first round of adjunct professor hires. U.S. Army funding had been approved, and candidates had been identified through the Kabul University Dean of Engineering Faculty. We completed the hiring process by interviewing the candidates, making four selections, and coordinating the preparation of their contracts.

Three of the initial four hires proved to be highly successful. The first two were recent graduates of Kabul University's five-year civil and mechanical engineering bachelor's degree programs. Despite their lack of graduate education (there are currently no functioning graduate programs in Afghanistan), these young professors possess relatively strong technical abilities and English language skills, a notably pro-western outlook, and exceptional commitment to serving their country through engineering education. Our third hire was a more seasoned associate professor who had earned a master's degree in India following the completion of his undergraduate degree at Kabul University. He has very strong technical and language skills, augmented by professional experience in public information. The only unsuccessful hire was an instructor who was well qualified but was offered a more lucrative contract to work for the United Nations as a consultant. Our unanticipated competition with the UN for engineering talent is indicative of the long-term challenge that NMAA will face in building a permanent faculty. (This issue is discussed in greater detail later in this paper.) Nonetheless, we were able to fill this position with a well qualified alternate candidate from Kabul University with little difficulty.

The Dean of Engineering Faculty at Kabul University was instrumental in the success of this hiring process. He viewed the NMAA adjunct positions as excellent developmental opportunities for his faculty, and he actively encouraged them to apply. He also helped identify candidates with the requisite technical background and English language skills. This hiring process was also aided by our ability to employ the adjuncts on U.S. contracts at competitive salaries. ${ }^{*}$ Other NMAA faculty hires had been implemented through the Afghan Ministry of Defense and, as a result, were hindered by less competitive salary levels and significantly greater administrative problems.

Subsequent rounds of faculty hiring have followed the same procedure and have been equally successful. In general terms, the employment of Kabul University adjunct instructors has been very effective in jump-starting the NMAA civil engineering program. However, this heavy reliance on adjuncts is not sustainable in the long term. As of this writing, the NMAA has hired only a single permanent faculty member for its Civil Engineering Department. For long-term program management and continuity, additional permanent faculty will need to be hired. Given the scarcity and high demand for qualified engineers in Afghanistan, long-term development of the faculty is certainly the NMAA civil engineering program's greatest strategic challenge.

\section{Curriculum Design}

Our design for the NMAA civil engineering curriculum was based on three principal criteria:

\footnotetext{
* The "highly competitive salary" paid to an assistant professor is $\$ 600$ per month.
} 
The curriculum must be relevant. The coursework should be consistent with infrastructure development practices and priorities in Afghanistan, and it must reflect the knowledge and skills required of officers in the Afghan National Army.

The curriculum must be accreditable, based on western standards. The NMAA Superintendent and Dean have expressed their strong desire that the academy have accredited degree programs as soon as possible. Because of political, financial, and structural issues between the Afghan Ministry of Defense and the Ministry of Higher Education, we found that accreditation of the NMAA curriculum within the Afghan system will be infeasible for the foreseeable future. Pursuing international accreditation through ABET or one of the U.S. regional accrediting bodies (e.g., Middle States Commission on Higher Education) is a more practical alternative. In our estimation, the NMAA will not be able to meet U.S. accreditation standards for several years at best; nonetheless, we sought to create a curricular framework that would be accreditable at some time in the future, when the institution's management processes, faculty credentials, academic standards, and facilities can be brought up to the appropriate level of quality.

The curriculum must be conducive to implementation by a relatively inexperienced faculty. The NMAA adjunct instructors also teach full course loads at Kabul University. They have very little time during the academic year for course development, and they lack formal training in course management and pedagogy. They receive mentorship from U.S. advisors, but this assistance tends to be discontinuous. Thus the NMAA engineering courses should be reasonably well structured, and there must be a mechanism for their long-term management.

To ensure that the curriculum will be relevant, we interviewed and coordinated with a wide variety of experts and stakeholders. These included:

- Heads of the NMAA Math Department and Basic Sciences Department - to assess the level of cadets' prerequisite knowledge in relevant math and science topics.

- Engineers from the U.S. Army Corps of Engineers Afghanistan Engineer District and the United Nations Office for Project Services - to identify Afghanistan's infrastructure development needs, common construction practices, and relevant codes and standards.

- Representatives of the installation management agency of the Afghan Ministry of Defense - to identify the needs of the defense agency most likely to employ graduates of the NMAA civil engineering program.

- Engineering professors from Kabul University - to ascertain the standards and common practices of higher education in Afghanistan, and to benchmark against the recently redesigned engineering curriculum at Kabul University.

- Officials from the Afghan Ministry of Higher Education - to investigate accreditation standards and practices.

Our key observations from these consultations included the following:

- Afghanistan's most critical civil infrastructure needs are road construction, water distribution, wastewater and solid waste disposal, and power generation.

- Military engineers in Afghanistan are likely to be heavily involved in managing construction contracts. 
- Most commercial building construction in Afghanistan is reinforced concrete and masonry. Steel construction is present but less common. Timber construction is rare in most regions of the country.

- Afghanistan is in a seismically active region.

- Most major construction work in Afghanistan is administered in the English language.

- Kabul University recently implemented all-English instruction and textbooks in all of its engineering programs.

- The NMAA core math and physics courses are currently providing a level of prerequisite knowledge significantly below our expectations of equivalent courses in the U.S.

To ensure that the curriculum will be accreditable in the future, we included an adequate number of courses to satisfy the ABET Criterion 5 requirement for one year of math and basic sciences and one and one-half years of engineering topics. ${ }^{7}$ Assuming three credit hours per course, these requirements can be met with 11 math and basic science courses (i.e., one course more than the ten already present in the NMAA core curriculum) and 16 engineering courses. We also included a capstone design experience to meet the ABET Criterion 5 requirement for "a major design experience based on the knowledge and skills acquired in earlier course work."7

To ensure that the curriculum will be conducive to implementation, we used existing USMA engineering courses as the starting point for the corresponding NMAA courses wherever it made sense to do so. By providing for consistency between USMA and NMAA courses, we were able to expedite the course development process and, more importantly, to provide for long-term mentorship by USMA faculty and long-term updates of NMAA courses (through a linkage to the USMA course assessment process). These advantages notwithstanding, we also recognized that rigid consistency between USMA and NMAA courses could compromise the relevance of the NMAA curriculum, as the two institutions serve markedly different constituencies. Thus we used USMA courses only as a starting point. In all cases, we adjusted the content of the corresponding NMAA courses to reflect an Afghan context, and we added new courses as necessary.

The resulting NMAA civil engineering curriculum is summarized in Table 1 below. The courses listed in this table are the "courses in major" identified in Figure 1 above.

Course Development and Implementation

As of this writing, all of the Semester 5 and 6 courses have been designed and successfully implemented during the most recent academic year, March-December 2007 (Islamic Year 1386). Development of Semester 7 courses has been initiated by a new team of USMA faculty mentors who deployed to Kabul in January 2008.

In general, the development of each course has been a collaborative effort involving a U.S. faculty mentor and the Afghan instructor designated to teach the course. The products of this collaborative effort have typically included the following for each course:

- Textbook selection

- Course syllabus, which lists lesson titles, lab exercises, and course grading policies 
- Course study guide, including learning objectives, an orientation, and a reading assignment for each lesson in the course

- Homework assignments, laboratory exercises, and design projects

- In some cases, instructor "board notes" for each individual lesson in the course ${ }^{8}$

\begin{tabular}{|c|c|c|}
\hline Semester & Course Title & Remarks \\
\hline \multirow[t]{3}{*}{5} & $\begin{array}{l}\text { Introduction to Engineering Mechanics and } \\
\text { Design* }\end{array}$ & $\begin{array}{l}\text { Statics and mechanics of materials, with a } \\
\text { substantive design project }\end{array}$ \\
\hline & Civil Engineering Fundamentals* & $\begin{array}{l}\text { Introduction to the CE discipline, plus } \\
\text { surveying, CAD, and site engineering }\end{array}$ \\
\hline & Engineering Mathematics & \\
\hline \multirow[t]{4}{*}{6} & Construction Management & $\begin{array}{l}\text { Project delivery methods, estimating, } \\
\text { scheduling, flexible pavements, base camp } \\
\text { design, and a substantive design project }\end{array}$ \\
\hline & Mechanics of Materials & $\begin{array}{l}\text { Advanced topics in mechanics of materials, } \\
\text { plus introduction to materials science }\end{array}$ \\
\hline & Environmental Engineering & $\begin{array}{l}\text { Water, wastewater, solid \& hazardous } \\
\text { waste, and air pollution }\end{array}$ \\
\hline & Thermodynamics \& Fluid Mechanics & Includes steam power plant design \\
\hline \multirow[t]{5}{*}{7} & Hydrology and Hydraulic Design & \\
\hline & Geotechnical Engineering & \\
\hline & Design of Reinforced Concrete Structures & \\
\hline & Technical Communication & \\
\hline & Structural Analysis & \\
\hline \multirow[t]{4}{*}{8} & Dynamics & $\begin{array}{l}\text { Emphasis on structural dynamics, with } \\
\text { introduction to seismic design }\end{array}$ \\
\hline & Transportation Engineering & Emphasis on road design \\
\hline & Design of Steel Structures & \\
\hline & Civil Engineering Design Project & \\
\hline
\end{tabular}

*These courses also serve as the two-course core engineering sequence for non-engineering majors.

Table 1. NMAA Civil Engineering Curriculum

By far the greatest challenge affecting all aspects of the course development process has been the decision concerning the language in which engineering instruction will be offered. The official language of NMAA (and one of two principal languages in Afghanistan) is Dari. The Afghan leaders of the academy expect all instruction to be delivered in this language. However, there are no credible engineering textbooks written in Dari. Farsi, the language of Iran, is very similar to Dari, and other academic subjects at NMAA have been taught with Farsi textbooks obtained from Iranian sources. But even beyond the political implications of the U.S. Army purchasing Iranian textbooks, we found that Farsi engineering texts would be unsuitable for the NMAA, because of significant differences in the ways that Dari and Farsi handle technical terminology. More importantly_as our Kabul University faculty colleagues repeatedly reminded us- the language of engineering in Afghanistan is English. Even if high-quality Dari texts did exist, teaching engineering courses entirely in Dari would not effectively prepare NMAA graduates for professional practice in their own country. Unfortunately, few cadets enter the academy with significant English language proficiency, and only approximately half of the cadets in any given class study English at NMAA. Fortunately, only the very brightest cadets in each class are 
allowed to major in engineering, and most of these cadets do study English. We conducted some informal language testing of the NMAA's first cohort of engineering majors and found that all had at least some basic-level English proficiency, and all had a strong desire to improve their English skills. As such, we concluded that offering engineering instruction in English would be feasible.

After much deliberation we proposed, and eventually gained the Dean's approval for, the following set of policies:

- All engineering courses will use English-language textbooks. Given that much of the content in engineering texts consists of graphics and equations, these books will be of some use even to cadets with limited or no English language proficiency.

- The two core engineering courses, which are taken by all cadets, will have all curricular materials translated into Dari, to include detailed study notes outlining the key learning points for each lesson.

- For all of the remaining engineering courses, which are taken only by civil engineering majors, only the course syllabus will be translated into Dari. All other curricular materials will be provided to the cadets in English.

- Classroom instruction will be offered in a mix of Dari and English, to ensure that cadets with limited English proficiency can glean the key learning points from each lesson, while also providing opportunities for all cadets to improve their English skills.

- During Semesters 5 and 6, engineering majors will use their engineering textbooks in their English language courses to reinforce their understanding of technical terminology.

We faced numerous other challenges in developing courses for NMAA, including:

- Effecting coordination and curricular development through interpreters with little or no technical background.

- Adapting our USMA curricular materials to a totally foreign system of academic administration and scheduling.

- Adapting course content to the capabilities of students who are, for the most part, inadequately prepared for college-level study as a result of Afghanistan's shattered elementary and secondary school systems. (This issue is explored in greater detail in Reference 9.)

\section{Laboratory Development}

In conjunction with our curriculum development work, we also designed and procured equipment for two new laboratory facilities. One, a computer-aided engineering lab, was equipped with 20 state-of-the-art computer workstations and associated software and furniture. The other, a testing laboratory, incorporates standard materials testing equipment for concrete and soil, small hand-operated uniaxial tension and torsion testing machines, a structural testing frame, a flume, and total station surveying equipment. Because of the long lead time on ordered equipment, difficulties getting the equipment into Afghanistan, and problems with software licensing, we were unable to get either lab fully operational by the time our deployment ended. Completion of the labs and integration of laboratory testing into NMAA courses will be accomplished by USMA mentors during future deployments. 


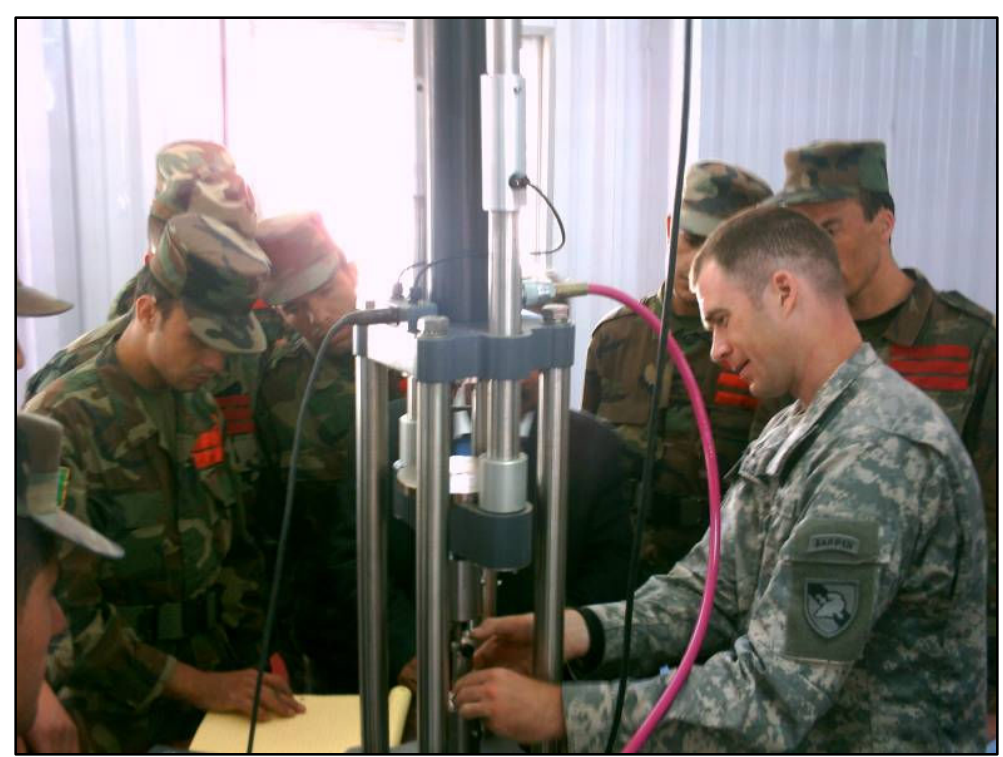

Figure 3. Gash demonstrates a uniaxial tension test to Afghan cadets.

Assessment and Lessons Learned

Development of the civil engineering program at the NMAA is a work in progress. The creation of new courses will continue through the end of the next academic year in January 2009. Thereafter, much work will still be required for the refinement and integration of courses and labs, for faculty development, and for the expansion of the program to accommodate larger incoming classes. A comprehensive, outcomes-based assessment of the program will not be possible until NMAA produces its first graduates in 2009. Nonetheless, with one full academic year of program implementation complete, an interim assessment is both possible and useful. This interim assessment of program effectiveness is reported separately in Reference 9.

In developing the program, we also learned several broader lessons that can reasonably be applied to similar engineering capacity-building projects elsewhere in the developing world. These lessons are as follows:

Physical presence matters. Facilitating development in a place like Afghanistan involves, first and foremost, building personal relationships and earning trust. Such relationships cannot be established and nurtured from afar. While in Afghanistan, we encountered several aid programs that were foundering because well-meaning donors chose to administer their projects from outside of the country. Some of these programs attempted to provide support that was unwanted or ill-suited to the needs of the aid recipients. (For example, one university-based project sought to provide distance education courses to students at Kabul University, even though Kabul University's internet connectivity was entirely inadequate.) Other programs provided funding that was misspent, for lack of direct oversight. (For example, a major externally funded renovation of Kabul University's engineering building produced a retrofitted heating system that failed within weeks of project completion. Other donors provided the university with sophisticated laboratory equipment, even though the Afghans had neither the expertise nor the resources to operate it.) Without on-the-ground mentorship and active oversight, developmental aid is too often wasted. 
Cultural awareness is paramount. In preparation for our deployment, we read extensively about Afghanistan's history and culture, and we learned a few simple phrases in Dari. In our interactions with Afghan colleagues, we made a concerted effort to demonstrate interest in their culture and customs. This interest paid large dividends in strengthening our working relationships with our hosts.

Members of the host institution must own the development process. Having suffered through three decades of near-constant war and repressive governments, Afghanistan's higher education system and academic culture are as badly broken as its physical infrastructure. The Afghans we met were hungry for guidance on how to rebuild. Under the circumstances, there was a natural tendency for us to step in and take charge - to dictate the direction and pace of change, and to impose our own ideas upon our hosts. Indeed, the Afghans were often content to have us take charge. Doing so would have been counterproductive, however, as the Afghans must ultimately take control of their own destiny. Thus we had to be constantly conscious of our role as mentors-not program developers. We made every effort to engage our Afghan colleagues as active participants in all aspects of program development, and we always deferred to them for final programmatic decisions.

Be patient. Capacity-building in the developing world is likely to involve some measure of cultural change. For example, goal-setting, planning, and assessment were foreign ideas to many of the Afghans we met. Helping our colleagues understand and internalize the value of these activities was (and continues to be) a gradual process. Cultural change must necessarily be evolutionary. Thus, throughout our involvement in this project, we have learned to seek progress in small increments and to adopt a long-term perspective on the prospects for success.

Create a mechanism for long-term continuity of effort. Our work at the NMAA was one small portion of a large, complex enterprise that has involved over thirty faculty members, contributing during a series of intense two- to three-month periods distributed discontinuously over five years. In reviewing the work of our predecessors, we found frequent instances of "reinventing the wheel" and of positive changes that failed to take hold because they were not passed along to successors. Upon our return to USMA we participated in the creation of a NMAA Continuity Committee designed to maintain historical files and to bridge the gaps between successive faculty deployments. We expect that capacity-building projects in other parts of the developing world are prone to suffer from this same problem and would benefit from the creation of a similar coordinating structure.

Seek a balance between employing engineers and growing engineers. An essential component of capacity-building is developing human capital-imparting critically needed professional skills to people who will then contribute to the long-term development of the nation. In this context, it makes perfect sense for a capacity-building project to employ local engineers in both engineering practice and education, to the greatest extent possible. Doing so provides professional development for the engineers and an incentive for future generations to enter the profession. The most vexing problem we observed in Afghanistan is that the demand for qualified engineers far exceeds the supply. Non-governmental organizations and, to a lesser extent, the U.S. Government are able to offer very lucrative salaries to Afghan engineers and thus are able to hire 
the best and brightest-much to the detriment of Afghanistan's own universities. At Kabul University, faculty members are so heavily engaged in consulting for western aid agencies that they can devote only minimal attention to their teaching responsibilities. Students, the nation's future engineers, suffer the consequences. A government entity like NMAA, constrained to pay its permanent faculty according to standardized Ministry of Defense pay scales, cannot possibly provide competitive salaries for engineers. As a result, the development of a well qualified permanent faculty remains the single greatest threat to the long-term success of this institution. In effect, the nation's current demand for engineers is compromising its capacity to grow new engineers for the future. In our view, it falls to the employers of these engineers to recognize the problem and seek a better balance.

\section{References}

1. Peat, R. and Rice, F., "Afghan Military Academy Opens Gates to Future Leaders," American Forces Press Service, March 28, 2005. Accessed at http://www.globalsecurity.org/military/library/news/2005/03/mil-050328afps03.htm, December 29, 2007.

2. The New York Times, "West Point Is Scouted as a Model for Kabul," May 8, 2004.

3. Wallace, D., "Coalition helps build Afghanistan's 'West Point'," Army News Service, September 7, 2004. Accessed at http://www4.army.mil/ocpa/read.php?story_id_key=6331, December 29, 2007.

4. Central Intelligence Agency, "CIA World Fact Book - Afghanistan,” December 13, 2007. Accessed at https://www.cia.gov/library/publications/the-world-factbook/print/af.html, December 29, 2007.

5. Harpviken, K. B., "Ethnic Conflict—Afghanistan." Accessed at http://www.bookrags.com/research/ethnicconflictafghanistan-ema-02/, December 30, 2007.

6. Marlowe, A., "With the Afghan Army,” Wall Street Journal, December 4, 2007.

7. ABET Engineering Accreditation Commission, "Criteria For Accrediting Engineering Programs, Effective for Evaluations during the 2008-2009 Accreditation Cycle, "November 3, 2007. Accessed at http://www.abet.org/forms.shtml, January 3, 2008.

8. Ressler, S. J., R. W. Welch, and K. F. Meyer (2004). "Organizing and Delivering Classroom Instruction.” Journal of Professional Issues in Engineering Education and Practice, 130 (3), 153-156.

9. Ressler, S. J., et. al, "Implementing a Civil Engineering Program for the National Military Academy of Afghanistan," Proceedings of the 2008 American Society for Engineering Education Annual Conference, Pittsburgh, June 2008. 